\title{
Tobacco Mosaic Virus (TMV) Infection in Several Varieties and Ages of Tomato Plants (Lycopersicum esculentum, Mill.)
}

\author{
Nurhayati DAMIRI ${ }^{1, *}$, Amat NURKHOLIS ${ }^{1}$, \\ Yulia PUJIASTUTI ${ }^{1}$ and Supli Effendi RAHIM ${ }^{2}$ \\ ${ }^{I}$ Department of Plant Pests and Diseases, Faculty of Agriculture, Sriwijaya University, \\ South Sumatra, Indonesia \\ ${ }^{2}$ Bina Husada College of Health Sciences, South Sumatra, Indonesia
}

('Corresponding author’s e-mail: nurhayatidamiri@yahoo.co.id)

Received: 21 July 2017, Revised: 1 August 2018, Accepted: 16 September 2018

\begin{abstract}
Disease caused by Tobacco Mosaic Virus (TMV) is an important disease in tomato plants, and is transmitted through both natural and artificial wounds. TMV attacking tomato plants can cause qualitatively and quantitatively lower production. The decline in production by TMV attack can reach $60 \%$. This research was conducted at the greenhouse of the Plant Protection Department, Faculty of Agriculture, University of Sriwijaya, Indralaya, Ogan Ilir, South Sumatra, Indonesia, from January to June 2016. The purpose of this study was to assess TMV attack on different varieties and ages of tomato plants. This study was conducted using a factorial in Factorial Randomized Complete Block Design (FRCBD), with the first factor, namely plant varieties, and the second factor, age stage of plants, repeated 3 times. The results showed that the most susceptible tomato was "Permata", with the fastest incubation period and moderate disease severity. Age 8 weeks, when inoculation took place, was the most vulnerable time, with the highest disease severity. A combination of the tomato variety of Permata and an age stage of 8 weeks at the time of inoculation had the highest disease incidence.
\end{abstract}

Keywords: Tobacco Mosaic Virus, plant ages, varieties of tomatoes

\section{Introduction}

Tomato (Lycopersicum esculentum Mill.) is an important vegetable crop and planted widely throughout the world, including Indonesia. This crop is a horticultural commodity with high economic value and requires serious treatment, especially in terms of increased production and fruit quality. As a tropical country, Indonesia has the potential, and opportunities that are large enough, to take advantage of business opportunities in the field of horticulture, particularly tomato [1].

According to [2], the production of Indonesian tomatoes in 2014 was as much as 915,987 tons, or about 7.69 percent of the national vegetable production, which ranks the fifth. The Indonesian tomato production center is Java, with a total production of 434,202 tons, or about 47.40 percent of the total national production of tomatoes. West Java is the largest tomato producer, with a production of 304,687 tons, or 33.26 percent of the total national production of tomatoes. Tomato production in 2014 decreased by $7.74 \%$ compared to production in 2013 [2]. In addition to the reduction of land, there are obstacles in the field, such as pests and virus diseases, among others. Low tomato yield is due to a number of factors, i.e., lack of improved well-performing varieties, poor fruit setting by heavy rain, and high temperatures which limit pollination, more specifically, fecundation plus pollen viability, pests, and diseases [3]. Generally, a number of viruses singly infecting the host is known to have the potential to inflict severe losses [4]. 
http://wjst.wu.ac.th

In Indonesia, viruses that are attacking tomato plants are the Tobacco Mosaic Virus (TMV), Potato Virus Y (PVY), and Cucumber Mosaic Virus (CMV). These 3 viruses together can reduce production by up to $50 \%$, depending on the age and variety of the plant when infected $[5,6]$. TMV can result in poor fruit quality and reduce the value of the crop on the commercial fresh market and may reduce the production by $20-60 \%$ [7,8]. This virus, which is seed-borne, is commonly found in tomato plants, and can be transmitted both mechanically or by seed [9,10]. Damiri [11] stated that, in the field, the virus can persist in soil or tobacco debris or in an alternate host. Many factors influence the development of TMV in tomato plants. This paper reports a study on the effect of TMV infection at various ages of 3 tomato varieties.

\section{Materials and methods}

This research was carried out in a greenhouse at the Plant Pests and Disease Department, Faculty of Agriculture, University of Sriwijaya, Indonesia, between January and June 2016. The research was arranged in a Factorial Randomized Complete Block Design (FRCBD), with plant varieties as the first factor, and plant age stages as the second factor. The first factor consisted of 3 local varieties, Chung, Tysera, and Permata, whereas the second factor consisted of 4 levels, 2 weeks after transplanting (WAT), 4 WAT, 6 WAT, and 8 WAT. Each treatment was replicated 3 times, and each replicate consisted of 2 polybags, with each polybag containing one tomato plant.

\section{Preparation of host plant and inoculums}

Each tomato variety seedling was grown until 2 weeks old and then transplanted into polybags containing $10 \mathrm{~kg}$ of sterile mix of topsoil and organic soil (2:1). Inoculum was prepared by fresh freezing TMV symptomatic tissue, which was derived from the Bandung Research Centre for Vegetable. The inoculum was put in liquid nitrogen, then homogenized in cold phosphate buffer, pH 7.2 (1:10 weight by volume). Inoculation was conducted mechanically by rubbing a single young leaf, which was earlier dusted with carborundum 600 mesh, with inoculums of the respective virus. Plants were maintained, including by fertilizing, watering, and weeding.

The parameters observed in this research were the incubation period, disease severity, and first production (number of fruits and the weight of total fruits yield) for each plant. The intensity of virus attacks was calculated using the formula from [12], as follows;

$\mathrm{I}=\sum \mathrm{n} . \mathrm{V} \times 100 \%$

N.V

where: $\mathrm{I}=$ intensity attack symptoms

$\mathrm{n}=$ number of plants included in a particular symptom scale

$\mathrm{v}=$ value of certain symptoms score

$\mathrm{N}=$ number of plants observed

$\mathrm{V}=$ value of the highest severity score

Symptom severity scores were classified as follows:

$0=$ plants not showing symptoms

$2=$ plants showing mosaic and yellow groove visible $(>25-50 \%)$

$3=$ plants showing mosaic and changes in growth $(>50-75 \%)$

$4=$ plants showing symptoms of severe mosaic, deformed growth, and dwarf plants $(>75-100 \%)$

The data were analyzed using the analysis of variance (ANOVA), and comparison among means with Duncan's Multiple Range Test (DMRT) [13]. 
http://wjst.wu.ac.th

\section{Results and discussion}

The results analysis of the overall effect in this research showed that varieties and plant age stages significantly affected the incubation period, disease severity, and plant production. The interaction of the tomato varieties and the age stages significantly affected the disease severity; however, there was no interaction effect between varieties and age stages on incubation period and production (number and weight of fruit yield) (Table 1).

Table 1 Summary of effect of Tobacco Mosaic Virus infection on incubation period, disease severity, and tomato production

\begin{tabular}{llccc}
\hline \multirow{2}{*}{ No } & Parameters observed & \multicolumn{2}{c}{ Treatment } \\
\cline { 3 - 4 } & & Varieties & Age stages & Varieties*Age stages \\
\hline 1 & Incubation period & $* *$ & $* *$ & $\mathrm{~ns}$ \\
2 & Disease severity & $* *$ & $* *$ & $* *$ \\
3 & Production (fruits number and weight) & $* *$ & $* *$ & $\mathrm{~ns}$ \\
\hline
\end{tabular}

Note: $* *=$ significantly different at $\mathrm{p}<0.01$ and $\leq 0.05$, respectively; ns $=$ not significantly different

Result of statistical testing showed that tomato varieties and age stages significantly affected incubation period (Tables 2 and $\mathbf{3}$ ).

Table 2 Effect of tomato varieties on incubation period of Tobacco Mosaic Virus

\begin{tabular}{lc}
\hline Tomato varieties & Incubation period (days after inoculation) \\
\hline Tysera & $9.54 \mathrm{a}$ \\
Permata & $10.25 \mathrm{ab}$ \\
Chung & $11.04 \mathrm{~b}$ \\
\hline
\end{tabular}

Means in a column followed by the same letter are not significantly different $(\mathrm{P} \geq 0.05, \mathrm{DMRT})$

Table 2 showed that the incubation period on Tysera was not significantly different from Permata, but significantly different from that of the Chung variety $(P \leq 0.05)$. The incubation of Permata was not significantly different from that of the Chung variety. The disease symptoms showed by 3 tomato varieties ranged from necrosis to mild mosaic, mosaic symptoms on leaves visible, initially green leaves turned into yellowish, leaves undergoing chlorosis, leaves rather wrinkled, and malformations (see Figure 1). 
http://wjst.wu.ac.th

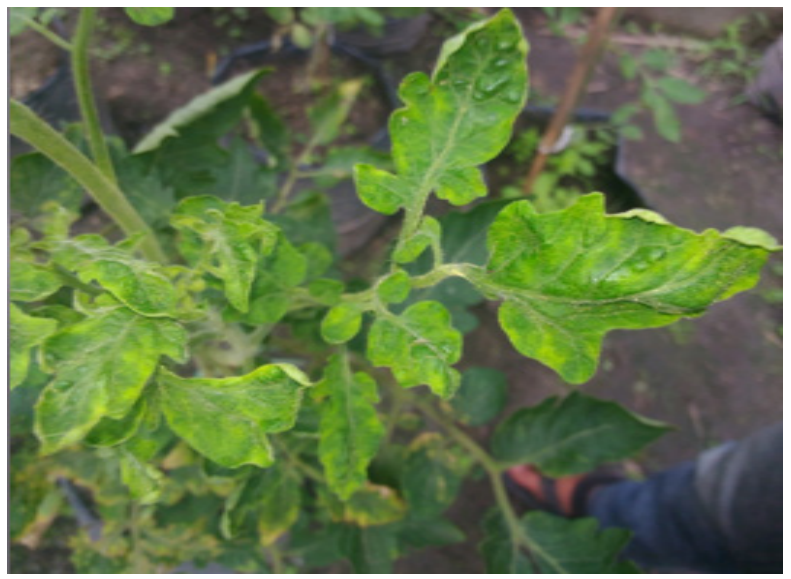

Figure 1 Symptom of Tomato Mosaic Virus on tomato leaves

Table 3 shows that the incubation period on a tomato plant when inoculated at the ages of 8 WAT, 6 WAT, and 4 WAT was not significantly different from one to another, but significantly different from that of the age of 2 WAT. Age of tomato plants when inoculated at the age of 8 weeks showed the fastest incubation period, with a time of 9.33 days, while the longest incubation period of time occurred at 2 WAT, being 12 days.

Table 3 Effect of tomato age stages on incubation period of Tobacco Mosaic Virus

\begin{tabular}{lc}
\hline \multicolumn{1}{c}{ Age stages } & Incubation period (days after inoculation) \\
\hline 8 weeks after transplanting (8 WAT) & $9.33 \mathrm{a}$ \\
6 weeks after transplanting (6 WAT) & $9.56 \mathrm{a}$ \\
4 weeks after transplanting (4 WAT) & $10.22 \mathrm{a}$ \\
2 weeks after transplanting (2 WAT) & $12.00 \quad \mathrm{~b}$ \\
\hline
\end{tabular}

Means in a column followed by the same letter are not significantly different $(\mathrm{P} \geq 0.05, \mathrm{DMRT})$

Factors that affect the fast or slow incubation period of the plants include the factor of age of the plant. Beside the age of plant, incubation time was also affected by host factor, virus concentration, environmental factor, virus character, virus development speed in tissue, and plant susceptibility toward infection [14]. According to Kusumawati et al. [15], the younger the age of inoculation, the faster the incubation period. However, in this study, what happened was the opposite, where the fastest was on the tomato age of $8 \mathrm{WAT}$. It is presumed that susceptibility of tomato plants to TMV infection was at older than $8 \mathrm{WAT}$, because at the time of inoculation TMV, the tomato plants were already flowering, so requiring a lot of energy, while at the same time having infection by TMV being present. Decrease in plant susceptibility at the time of flowering and fruiting was possibly due to the fact that at the time more metabolism processes were being used on the process of flowering and fruiting. At $8 \mathrm{WAT}$, the tomato plant requires more energy for the flowering and fruiting for production processes, resulting in a lowering of the plant susceptibility. According to Scott et al. [16], if the development of early flowering plants is retarded by suboptimal growth conditions, inoculated plants appear more susceptible to the virus, and systemic infections become more widespread. In addition, in a certain plant, there is an anti-virus factor (AVF) [17]. 
http://wjst.wu.ac.th

Anti-virus factor (AVF) is one of the factors that affect resistance and vulnerability. AVF that was present during the vegetative phase can suppress the replication of viruses in plants. In contrast, during the phases of flowering and fruiting formation in general, AVF is at minimum, as growth regulators such as IAA (Indole acetid acid) and BAP (benzylaminopurine) get reduced. The decrease in plant ability to produce AVF causes inability in the plants to prohibit virus multiplication $[17,18]$.

Further tests of the effect of TMV infection on tomato varieties, age stages, and the interaction between varieties and age stages were significantly different (Tables 4 - 6). Table 4 showed the disease severity development from the first week to the fifth week. It was clear that the highest disease severity at the fifth week was found in the Permata variety, which was also significantly different $(\mathrm{P} \leq 0.05)$ from that of the Tysera and Chung varieties, respectively. Between the Tysera and Chung varieties, there was no difference in disease severity from one to another.

Table 4 Effect of TMV infection on development of disease severity on tomato varieties

\begin{tabular}{cccccc}
\hline & \multicolumn{5}{c}{ Disease Severity at week (\%) } \\
\cline { 2 - 5 } Variety & $\mathbf{1}$ & $\mathbf{2}$ & $\mathbf{3}$ & $\mathbf{4}$ & $\mathbf{5}$ \\
\hline Tysera & $3.16 \mathrm{a}$ & $3.90 \mathrm{a}$ & $4.32 \mathrm{a}$ & $5.38 \mathrm{a}$ & $7.46 \mathrm{a}$ \\
Chung & $8.74 \mathrm{ab}$ & $9.42 \mathrm{a}$ & $11.32 \mathrm{a}$ & $13.60 \mathrm{ab}$ & $17.04 \mathrm{a}$ \\
Permata & $15.05 \mathrm{~b}$ & $17.34 \mathrm{~b}$ & $19.95 \mathrm{~b}$ & $21.82 \mathrm{~b}$ & $28.73 \mathrm{~b}$ \\
\hline
\end{tabular}

Means in a column followed by the same letter are not significantly different $(\mathrm{P} \geq 0.05, \mathrm{DMRT})$

The severity of TMV on the tomato variety of "Permata" indicated that the severity of the attacks is higher compared to Tysera and Chung, allegedly because each tomato variety has different levels of resistance against TMV infection. It can be said that Permata is more susceptible to TMV infection. This is reinforced by the statement [19] that different varieties resulted in differences in regulatory genes that affect the level of resistance of the plant susceptibility to viral infections. On the fifth week of observation, disease severity in tomato varieties that were inoculated could be seen; plants inoculated at the age of 8,6 , and 4 weeks after transplanting were not significantly different from each other, but significantly different to disease severity in plants inoculated age of 2 weeks (Table 5).

Table 5 Influence of TMV infection on various age stages on development of disease severity tomatoes

\begin{tabular}{cccccc}
\hline \multirow{2}{*}{ Age stages (WAT) } & \multicolumn{5}{c}{ Diseases severity at week (\%) } \\
\cline { 2 - 6 } & $\mathbf{1}$ & $\mathbf{2}$ & $\mathbf{3}$ & $\mathbf{4}$ & $\mathbf{5}$ \\
\hline 2 & $2.71 \mathrm{a}$ & $3.93 \mathrm{a}$ & $5.48 \mathrm{a}$ & $6.51 \mathrm{a}$ & $7.62 \mathrm{a}$ \\
4 & $5.10 \mathrm{a}$ & $6.25 \mathrm{a}$ & $8.02 \mathrm{a}$ & $9.61 \mathrm{ab}$ & $13.41 \mathrm{ab}$ \\
6 & $10.92 \mathrm{ab}$ & $12.42 \mathrm{ab}$ & $14.50 \mathrm{ab}$ & $17,99 \mathrm{bc}$ & $23.23 \mathrm{~b}$ \\
8 & $17.21 \mathrm{~b}$ & $18.29 \mathrm{~b}$ & $19.45 \mathrm{~b}$ & $20.35 \mathrm{c}$ & $26.72 \mathrm{~b}$ \\
\hline
\end{tabular}

Means in a column followed by the same letter are not significantly different $(\mathrm{P} \geq 0.05, \mathrm{DMRT})$ 
http://wjst.wu.ac.th

In Table 6, the influence of the interaction between tomato variety and age stages on last observation showed that the highest disease severity found at the combined treatment of Permata and age stage 8 WAT (M3D8) was $42.94 \%$, while the lowest disease severity occurred in the combined treatment between Chung at age of 2 WAT (M1D2), at $1.99 \%$. This fact showed that Permata variety inoculated at the age of 8 WAT was very susceptible to TMV infection. Siadi et al. [20] suggested that in plants showing symptoms of viral infection, a disruption in the system of metabolism affects the rate of photosynthesis by decreasing the amount of chlorophyll, increasing respiration, increasing the activity of the enzyme, or lowering the amount of plant growth regulator, which may affect the functional systems of plant cells directly or indirectly. Some symptoms of viral infection are the results of alteration to plant growth and development [21].

Table 6 Effect of interaction between variety and plant age at inoculation on disease severity

\begin{tabular}{lccccc}
\hline \multirow{2}{*}{ Interaction } & \multicolumn{5}{c}{ Disease severity at week (\%) } \\
\cline { 2 - 6 } & $\mathbf{1}$ & $\mathbf{2}$ & $\mathbf{3}$ & $\mathbf{4}$ & $\mathbf{5}$ \\
\hline M1*D2 & $0.95 \mathrm{a}$ & $1.25 \mathrm{a}$ & $1.44 \mathrm{a}$ & $1.66 \mathrm{a}$ & $1.99 \mathrm{a}$ \\
M2*D2 & $2.30 \mathrm{ab}$ & $2.59 \mathrm{a}$ & $3.17 \mathrm{a}$ & $3.84 \mathrm{a}$ & $3.98 \mathrm{a}$ \\
M2*D4 & $2.49 \mathrm{ab}$ & $3.58 \mathrm{a}$ & $4.06 \mathrm{a}$ & $5.31 \mathrm{a}$ & $7.16 \mathrm{a}$ \\
M2*D8 & $2.64 \mathrm{ab}$ & $3.63 \mathrm{a}$ & $3.89 \mathrm{a}$ & $5.12 \mathrm{a}$ & $6.66 \mathrm{a}$ \\
M3*D2 & $4.89 \mathrm{abc}$ & $7.69 \mathrm{ab}$ & $11.82 \mathrm{abc}$ & $14.04 \mathrm{abc}$ & $16.91 \mathrm{abc}$ \\
M2*D6 & $5.20 \mathrm{abc}$ & $5.92 \mathrm{ab}$ & $6.17 \mathrm{ab}$ & $7.23 \mathrm{ab}$ & $12.07 \mathrm{ab}$ \\
M1*D4 & $5.28 \mathrm{abc}$ & $6.19 \mathrm{ab}$ & $9.32 \mathrm{abc}$ & $11.74 \mathrm{ab}$ & $14.38 \mathrm{abc}$ \\
$\mathrm{M} 3 * \mathrm{D} 4$ & $7.52 \mathrm{abc}$ & $8.99 \mathrm{ab}$ & $10.69 \mathrm{abc}$ & $11.78 \mathrm{ab}$ & $18.67 \mathrm{abc}$ \\
$\mathrm{M} 1 * \mathrm{D} 6$ & $10.49 \mathrm{abc}$ & $10.78 \mathrm{ab}$ & $14.03 \mathrm{abc}$ & $16.86 \mathrm{abcd}$ & $21.22 \mathrm{abcd}$ \\
$\mathrm{M} 3 * \mathrm{D} 6$ & $17.08 \mathrm{bcd}$ & $20.57 \mathrm{bc}$ & $23.33 \mathrm{~cd}$ & $29.70 \mathrm{~cd}$ & $36.41 \mathrm{~cd}$ \\
$\mathrm{M} 1 * \mathrm{D} 8$ & $18.25 \mathrm{~cd}$ & $19.50 \mathrm{bc}$ & $20.50 \mathrm{bcd}$ & $24.15 \mathrm{bcd}$ & $30.58 \mathrm{bcd}$ \\
$\mathrm{M} 3 * \mathrm{D} 8$ & $30.74 \mathrm{~d}$ & $32.12 \mathrm{c}$ & $33.95 \mathrm{~d}$ & $31.78 \mathrm{~d}$ & $42.94 \mathrm{~d}$ \\
\hline
\end{tabular}

Means in a column followed by the same letter are not significantly different $(\mathrm{P} \geq 0.05, \mathrm{DMRT})$

M1: Chung, M2: Tysera, M3: Permata and D2 = 2WAT, D4 =4WAT, D6 =6WAT, D8 = 8WAT

Curver and Padmanabhan [22] stated that there are connections between the interaction of specific virus factor with cell components and alternation in hormone synthesis and signaling. Interaction between the helicase domain of TMV replicase and several numbers of the auxin/Indole acetid acid (AUX/IAA) protein family have been reported [23]. The subcellular localization of these AUX/IAA proteins is altered, and their levels of accumulation lowered in the presence of TMV replicase. On other hand, their partial down regulation through virus-induced gene silencing gives rise to symptoms similar to those of TMV infection. Interaction of AUX/IAA proteins significantly lowers virus accumulation in mature plant leaves [24].

\section{Total and weight of fruits}

Further tests (Table 7) showed that, in the 3 varieties of tomato tested, the varieties of Permata and Tysera were not significantly different, but significantly different from the variety Chung. Total fruit weights of each variety were significantly different from each other. 
http://wjst.wu.ac.th

Table 7 The effect of TMV inoculation on first production of tomato varieties

\begin{tabular}{lcc}
\hline Tomato varieties & Total fruits/plant (number) & Total weight of fruit/plant (g) \\
\hline Permata & $1.80 \mathrm{a}$ & $44.22 \mathrm{c}$ \\
Tysera & $2.25 \mathrm{a}$ & $78.25 \mathrm{~b}$ \\
Chung & $3.25 \mathrm{~b}$ & $17.8 \mathrm{a}$ \\
\hline
\end{tabular}

Means in a column followed by the same letter are not significantly different $(\mathrm{P} \geq 0.05, \mathrm{DMRT})$

A further test of the influence of the age of the plant at the time of inoculation to TMV on the number and total fruits/plants showed that plants inoculated at the age of 2 weeks had the highest total number and weight of the fruit, averaging 4.00 of fruit/plant and 69.40 grams, respectively, significantly different to all the other treatments (Table 8).

Table 8 Effect of tomato age stages on TMV inoculation on the production

\begin{tabular}{lcc}
\hline Age when inoculated & Total of fruits/plant & Total weight of fruits/plant (g) \\
\hline 2 WAT & $4.00 \mathrm{~b}$ & $69.40 \mathrm{~b}$ \\
4 WAT & $2.22 \mathrm{a}$ & $45.50 \mathrm{a}$ \\
6 WAT & $2.17 \mathrm{a}$ & $38.80 \mathrm{a}$ \\
8 WAT & $2.27 \mathrm{a}$ & $47.90 \mathrm{a}$ \\
\hline
\end{tabular}

Means in a column followed by the same letter are not significantly different $(\mathrm{P} \geq 0.05, \mathrm{DMRT})$

Total weight of Chung was lower than the Tysera and Permata; this is because the morphology of fruits of the variety Chung is smaller compared to Tysera and Permata. Viral infection can affect physiological functions of plants. TMV can make alterations in carbohydrate distribution, so that the physiology of plant is disturbed [25]. Kusumawati et al. [15] stated that decrease in the weight of the fruit due to the presence of infection TMV makes the magnitude of the weight loss of fruit on each distinct variety possible because each has a level of resilience that differs in receiving the response to viral infection, and with different responses, the course will affect the growth and crop production. According to Taufik et al. [26], the inhibition of plant growth response is generally caused by viral replication contained in the plant. Viral replication occurs in both the inoculated part and in the part of plants that are not inoculated. It can even enter the transportation system of plants, so that the virus can spread systemically throughout the plant, resulting in the plants having stunted growth. Virus infection usually causes symptom resulting both in morphological and physiological alteration of the infected host plants, which always incurs inferior performance, such as decreased host biomass and crop yield loss.

\section{Conclusions}

From this study, it can be concluded that the most susceptible tomato variety is "Permata", with the fastest incubation period. Age 8 weeks when inoculation took place was the most susceptible, with the highest disease severity. A combination of tomato variety Permata and the age stage of 8 weeks at the time of inoculation has the highest disease severity. The Chung variety has the highest amount of fruit, but the least total weight fruit/plant. 
http://wjst.wu.ac.th

\section{Acknowledgements}

The authors would like to thank the Bandung Research Center for Vegetable for preparing TMV inoculum for this research, and Dr. Suparman SHK, head of the Plant Pest and Disease Department, whose help and support made possible the execution of the research and the writing of this paper.

\section{References}

[1] N Hanindita. Export Analysis of Tomato Fresh Indonesia. Executive Summary Business Management Graduate Program, Bogor Agriculture University, 2008.

[2] Central Bureau of Statistics. Statistical horticultural production in 2014, Available at: http://hortikultura.pertanian.go.id, accessed November 2015.

[3] JM Lyons and H Ferris. IPM for Tomatoes. University of California, Statewide IPM, Project Publication, 1985.

[4] OS Bolagun, L Xu, T Teraoka and D Husokawa. Effect of single and double infection with PVX and TMV on disease development, plant growth and virus accumulation in tomato. Fitopatologia Brasileira 2002; 27, 241-8.

[5] R Sutarya. Several important viruses on tomato plants in sub-district of Lembang (Bandung Regency). Bull. Penel. Hort. 1989, 72-9.

[6] N Damiri. Mixed viral infection and growth stage on Chilli (Capsicum annuum L.) production. Pertanika J. Trop. Sci. 2014; 37, 275-83.

[7] H Semangun. Diseases of Crops in Indonesia. Gajah Mada University Press, Yogyakarta, 2000.

[8] KBG Scholthof, JG Shaw and M Zaitlin. Tobacco Mosaic Virus: One Hundred Years of Contribution to Virology. American Phytophathology Society Press, 2000.

[9] R Hadas, M Pearlsman, T Gefen, D Lachman, E Hadar, G Sharabany and Y Antignus. Indexing system for tomato mosaic virus (ToMV) in commercial tomato lots. Phytoparasitica 2004; 32, 4214.

[10] DJ Lewandowski and WO Dawson. Tobamoviruses in Encyclopedia of Virology. In: A Granoff and RG Webster (Eds.). $2^{\text {nd }}$ eds. Vol. III, Academic Press Inc, New York, 1998, p. 1780-3.

[11] N Damiri. Virus Pathogen of Plants. Sriwijaya University Press, Palembang, Indonesia, 2012.

[12] LM Dolores. Management of pepper viruses. In: Proceedings of the AVNET II Final Workshop, Tainan, Taiwan, 1996, p. 334-42.

[13] KA Gomez and AA Gomez. Statistical Procedures for Agricultural Research. $2^{\text {nd }}$ eds. John Wiley and Sons, New York, 1984.

[14] H Susetio. 2011, Yellow Mosaic Disease on Long Bean: Response of Long Bean (Vigna sinensis L.) Cultivar and Efficiency of Spreading through Aphid (Aphis craccivora Koch.). B.Sc. Thesis of Agriculture Faculty, Bogor Agriculture University, Indonesia.

[15] DE Kusumawati, T Hadiastono and M Martosudiro. Resilience Five Plant Varieties Cayenne (Capsicum frutescens L.) against Infectious TMV (Tobacco mosaic virus) on Plants Different Age. Brawijaya University, Malang, Indonesia, 2013.

[16] ML Scott, T Robert and ST Howell. Effect of host plant development and genetic determinants on the long-distance movement of cauliflower mosaic virus in Arabidopsis. The Plant Cell 1993; 5, 191-202.

[17] ERD Purba. 2011, The Influence of Squesh Mosaic Comovirus Infection on the Mosaic Disease Development on Five Varieties of Cucumber. Ph.D. Thesis, Bogor Agriculture University.

[18] P Vidhayasekaran. Physiology of Disease Resistance in Plant. Vol. I. CRS Press, Florida, 1988.

[19] GN Agrios. Plant Pathology. $5^{\text {th }}$ eds. San Diego Academic Press, 2005.

[20] IK Siadi, IN Raka and IN Purwadi. Seed Production of Cayenne (Capsicum frutescens L.) Free of TMV (Tobacco mosaic virus) through Dry Heat Treatment. University of Udayana, Denpasar, Indonesia, 2012. 
[21] F Jay, Y Wang, A Yu, L Taconnat, S Pelletier, V Colot, JP Renou and O Voinnet. Misregulation of auxin response factor 8 underlies the developmental abnormalities caused by three distinct viral silencing suppressor in Arabidopsis. PLoS Pathog. 2011; 7, e1002035.

[22] JN Curver and MS Padmanabhan. Virus-induced disease: Altering host physiology on interaction at a time. Annu. Rev. Phytopathol. 2007; 45, 221-43.

[23] MS Padmanabhan, H Shiferaw and JN Culver. The tobacco mosaic virus replicase protein disrupts the localization and function of interacting Aux/IAA protein. Mol. Plant Microbe Interact. 2006; 19, 864-73.

[24] MS Padmanabhan, SR Kramer, X Wang and JN Culver. Tobacco Mosaic Virus replicaseauxin/indole acetic acid protein interaction, reprogramming the auxin response pathway to enhance virus infection. J. Virol. 2008; 82, 2477-85.

[25] S Balachandras, RJ Hull, Y Vaadia, S Wilf and WJ Lucas. Alternation in carbon partitioning induced by the movement protein of Tobacco Mosaic Virus originates in the mesophyll and is independent of change in the plasmodesmata size exclusion limit. Plant Cell Environ. 1995; 18, 1301-10.

[26] M Taufik, Sarawa, A Hasan and K Amelia. Analysis of Temperature's Effect and Moisture on the Development of Tobacco Mosaic Virus on Chilli. University of Haluoleo, Kendari, Indonesia, 2013. 